\title{
Prevalence of Complementary and Alternative Medicine-use by UK Cancer Patients: A Systematic Review of Surveys
}

Paul Posadzki*, Leala K Watson, Amani Alotaibi and Edzard Ernst

Complementary Medicine, Peninsula Medical School, Veysey Building, Exeter, EX2 4SG, UK

\begin{abstract}
Background: Cancer patients seem to frequently use Complementary and Alternative Medicine (CAM). However, estimates of the level of usage vary widely. This systematic review is aimed at determining the prevalence of CAM-use in cancer patients of the United Kingdom (UK).

Method: Five databases were searched for English language peer-reviewed surveys published between 01 January 2000 and 07 October 2011. In addition, relevant book chapters and our own departmental files were handsearched.

Results: 25 surveys were included with a total sample size of 6798 . Across all studies, the median prevalence rate of CAM-use was 30.5 (standard deviation=10.3). Herbal medicine was the most popular CAM modality, followed by homeopathy, aromatherapy, reflexology and relaxation. Conclusions: Many UK cancer patients use CAM. Oncologists need to be aware of these numbers as they can impact daily practice on the management of cancer patients.
\end{abstract}

Keywords: Complementary and alternative medicine; Cancer; Survey; Systematic review

\section{Introduction}

Complementary and alternative medicine (CAM) has been defined as "diagnosis, treatment and/or prevention which complements mainstream medicine by contributing to a common whole, satisfying a demand not met by orthodoxy, or diversifying the conceptual framework of medicine" [1].

Many cancer patients seem to experience both physical (e.g. more energy, less pain or nausea) as well as psychological (e.g. less anxiety or depression) benefits from using CAM [2,3]. Thus, many cancer patients try at least, one type of CAM [4]. Reliable prevalence data do, however, not exist.

The aim of this systematic review was to summarize and critically evaluate surveys monitoring the prevalence of CAM use by UK cancer patients during the past decade.

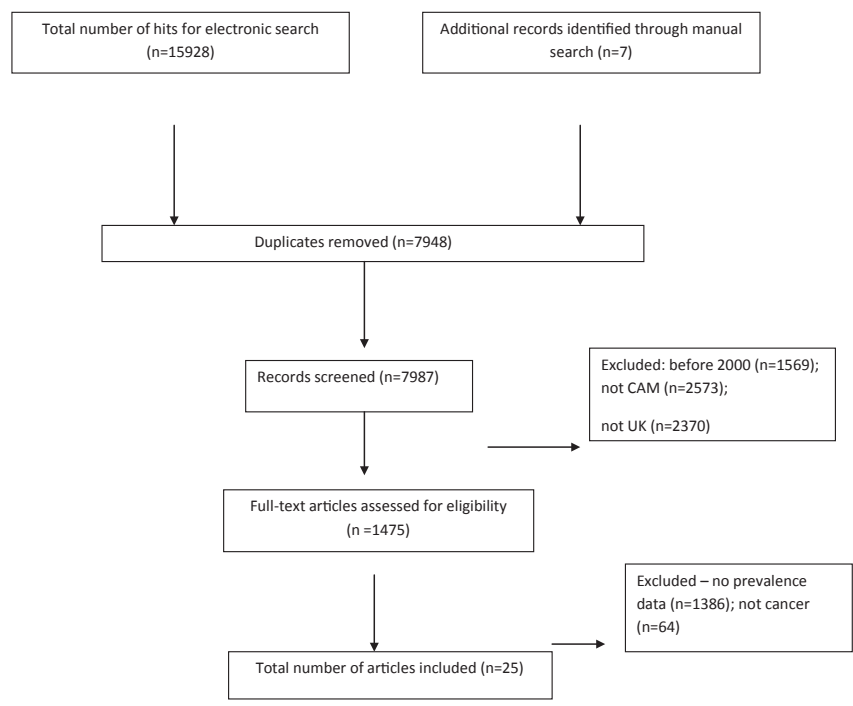

Figure 1: Flow Diagram.

\section{Method}

Systematic literature searches were performed for all English language references using AMED, CINAHL, COCHRANE, EMBASE and MEDLINE for surveys published between 01 January 2000 and 07 October 2011. Details of the search strategy are presented in the appendix. Additionally, relevant book chapters, review articles and our own departmental files were hand-searched for further relevant articles. Surveys which examined the prevalence of CAM use by UK cancer patients providing quantitative prevalence data were included. Surveys reporting only qualitative data were excluded. Information from the included surveys were extracted according to pre-defined criteria and assessed descriptively by two independent reviewers. Disagreements were settled through discussion.

Acupuncture/acupressure, Alexander Technique, aromatherapy, autogenic training, Ayurveda, (Bach) flower remedies, biofeedback, chelation therapy, chiropractic, Feldenkrais, herbal medicine, homeopathy, hypnotherapy, imagery, kinesiology, massage (any type), meditation, naturopathy, neural therapy, osteopathy, qi gong, reflexology, relaxation therapy, shiatsu, spiritual healing, static magnets, tai chi, and yoga were all considered as CAM. Non-herbal dietary supplements and vitamins, psychotherapy, physical exercises or some physiotherapeutic modalities such as electrotherapy or ultrasound were not considered to be CAM and therefore were excluded from analyses.

The top 5 CAM modalities (1=most popular) from each survey were ranked and averaged across the surveys to generate an overall

*Corresponding author: Paul Posadzki, Complementary Medicine, Peninsula Medical School, Veysey Building, Exeter, EX2 4SG, UK; E-mail: Paul.Posadzki@pcmd.ac.uk

Received March 30, 2012; Accepted April 25, 2012; Published April 27, 2012

Citation: Posadzki P, Watson LK, Alotaibi A ,Ernst E (2012) Prevalence of Complementary and Alternative Medicine-use by UK Cancer Patients: A Systematic Review of Surveys. J Integr Oncol 1:102. doi:10.4172/2329-6771.1000102

Copyright: @ 2012 Posadzki P, et al. This is an open-access article distributed under the terms of the Creative Commons Attribution License, which permits unrestricted use, distribution, and reproduction in any medium, provided the original author and source are credited. 
Citation: Posadzki P, Watson LK, Alotaibi A ,Ernst E (2012) Prevalence of Complementary and Alternative Medicine-use by UK Cancer Patients: A Systematic Review of Surveys. J Integr Oncol 1:102. doi:10.4172/2329-6771.1000102

Page 2 of 5

\begin{tabular}{|c|c|c|c|c|c|c|c|c|c|c|c|c|c|c|}
\hline $\begin{array}{l}1 \text { st } \\
\text { Au- } \\
\text { thor } \\
\text { (date) } \\
\text { [ref] }\end{array}$ & $\begin{array}{l}\text { Aim } \\
\text { (quote) }\end{array}$ & $\begin{array}{l}\text { Population } \\
\text { (n=)/cancer } \\
\text { site/loca- } \\
\text { tion }\end{array}$ & Method & $\begin{array}{l}\text { Sampling } \\
\text { technique }\end{array}$ & $\begin{array}{l}\text { Question(s) } \\
\text { asked } \\
\text { (quote) }\end{array}$ & $\begin{array}{l}\text { Response } \\
\text { rate }\end{array}$ & $\begin{array}{l}\text { Main find- } \\
\text { ings } \\
\text { Preva- } \\
\text { lence rate }\end{array}$ & $\begin{array}{l}\text { Most } \\
\text { popular } \\
\text { modalities }\end{array}$ & $\begin{array}{l}\text { Perceived } \\
\text { effective- } \\
\text { ness }\end{array}$ & $\begin{array}{l}\text { Adverse } \\
\text { effectS }\end{array}$ & Costs & $\begin{array}{l}\text { Predic- } \\
\text { tors of } \\
\text { CAM } \\
\text { modality } \\
\text { use }\end{array}$ & $\begin{array}{l}\text { CAM mo- } \\
\text { dality use } \\
\text { recom- } \\
\text { mended } \\
\text { by }\end{array}$ & $\begin{array}{l}\text { Other } \\
\text { relevant } \\
\text { findingS }\end{array}$ \\
\hline $\begin{array}{l}\text { Catt } \\
(2006) \\
{[23]}\end{array}$ & $\begin{array}{l}\text { To } \\
\text { explore } \\
\text { "the } \\
\text { prefer- } \\
\text { ences } \\
\text { for injec- } \\
\text { tion or } \\
\text { tablets } \\
\text { in the } \\
\text { admin- } \\
\text { istra- } \\
\text { tion of } \\
\text { breast } \\
\text { cancer } \\
\text { treat- } \\
\text { ment" }\end{array}$ & $\begin{array}{l}\text { 208/breast/ } \\
\text { UK }\end{array}$ & $\begin{array}{l}\text { Semi- } \\
\text { struc- } \\
\text { tured } \\
\text { inter- } \\
\text { view }\end{array}$ & n.m. & $\begin{array}{l}\text { Patients } \\
\text { were asked } \\
\text { about } \\
\text { treatment } \\
\text { they were } \\
\text { receiving }\end{array}$ & n.m. & $\begin{array}{l}53 \% \text { used } \\
\text { of non-pre- } \\
\text { scription } \\
\text { therapies } \\
\text { (currently) }\end{array}$ & $\begin{array}{l}\text { Garlic } \\
(3.4 \%), \\
\text { echinacea } \\
(1.9 \%), \text { black } \\
\text { cohosh } \\
(1.9 \%) \text {, Chi- } \\
\text { nese herbals } \\
(1.4 \%)\end{array}$ & n.m. & n.m. & n.m. & $\begin{array}{l}\text { Higher } \\
\text { educa- } \\
\text { tion, } \\
\text { higher } \\
\text { socio- } \\
\text { economic } \\
\text { status, } \\
\text { and } \\
\text { higher } \\
\text { internal } \\
\text { locus of } \\
\text { control }\end{array}$ & n.m. & $\begin{array}{l}53 \% \\
\text { were } \\
\text { self- } \\
\text { treating, } \\
\text { mainly } \\
\text { with } \\
\text { vitamin } \\
\text { and } \\
\text { mineral } \\
\text { supple- } \\
\text { ments }\end{array}$ \\
\hline $\begin{array}{l}\text { Van } \\
\text { Tonder } \\
(2009) \\
{[10]}\end{array}$ & $\begin{array}{l}\text { to com- } \\
\text { pare } \\
\text { "(...) the } \\
\text { usage, } \\
\text { ben- } \\
\text { efits and } \\
\text { side-ef- } \\
\text { fects of } \\
\text { dietary- } \\
\text { related } \\
\text { CAM } \\
\text { use } \\
\text { among } \\
\text { adult } \\
\text { cancer } \\
\text { patients } \\
\text { and } \\
\text { non- } \\
\text { cancer } \\
\text { adults } \\
\text { (...)" }\end{array}$ & $\begin{array}{l}\text { 98/various/ } \\
\text { England }\end{array}$ & $\begin{array}{l}\text { Self- } \\
\text { admin- } \\
\text { istered } \\
\text { ques- } \\
\text { tion- } \\
\text { naires }\end{array}$ & $\begin{array}{l}\text { Random } \\
\text { sampling } \\
\text { method }\end{array}$ & $\begin{array}{l}\text { Whether } \\
\text { health } \\
\text { profession- } \\
\text { als were } \\
\text { informed of } \\
\text { CAM usage? }\end{array}$ & $77.3 \%$ & $\begin{array}{l}36 \% \text { used } \\
\text { herbals }\end{array}$ & $\begin{array}{l}\text { Green tea } \\
(15 \%), \text { echi- } \\
\text { nacea }(9 \%), \\
\text { garlic }(5 \%)\end{array}$ & $\begin{array}{l}41 \% \\
\text { stated } \\
\text { they ben- } \\
\text { efited from } \\
\text { CAM }\end{array}$ & \begin{tabular}{|l|}
$2 \%$ \\
reported \\
AEs (diar- \\
rhoea)
\end{tabular} & n.m. & n.m. & $\begin{array}{l}\text { Family/ } \\
\text { neigh- } \\
\text { bours } \\
(30 \%) \text { and } \\
\text { the media } \\
(29 \%) \text {, } \\
\text { NHS staff } \\
(25 \%)\end{array}$ & $\begin{array}{l}54 \% \text { of } \\
\text { cancer } \\
\text { patients } \\
\text { informed } \\
\text { a health } \\
\text { profes- } \\
\text { sional } \\
\text { of their } \\
\text { CAM } \\
\text { use }\end{array}$ \\
\hline $\begin{array}{l}\text { Wer- } \\
\text { neke } \\
(2004) \\
{[22]}\end{array}$ & $\begin{array}{l}\text { "(...) to } \\
\text { estab- } \\
\text { lish the } \\
\text { type, } \\
\text { fre- } \\
\text { quency } \\
\text { and pat- } \\
\text { tern of } \\
\text { herbal } \\
\text { medi- } \\
\text { cine and } \\
\text { supple- } \\
\text { ment } \\
\text { use } \\
(\ldots) \text { ". }\end{array}$ & $\begin{array}{l}\text { 500/various/ } \\
\text { England }\end{array}$ & n.m. & n.m. & n.m. & $63.6 \%$ & $51.6 . \%$ & $\begin{array}{l}\text { Herbal medi- } \\
\text { cine }(10.4 \%)\end{array}$ & n.m. & $\begin{array}{l}12.2 \% \\
\text { patient } \\
\text { were } \\
\text { issued } \\
\text { warn- } \\
\text { ings from } \\
\text { pharmacy }\end{array}$ & n.m. & n.m. & n.m. & $\begin{array}{l}11.0 \% \\
\text { reported } \\
\text { supple- } \\
\text { ments in } \\
\text { higher } \\
\text { than } \\
\text { recom- } \\
\text { mended } \\
\text { doses. }\end{array}$ \\
\hline
\end{tabular}

AEs-adverse events

CAM-complementary and alternative medicine

Table 1: Main findings for specific CAM modalities.

ranking. Then the total number of surveys in which a particular CAM modality was the most prevalent/popular one was provided and the median of those figures was calculated. Where available, we calculated the average of the $\%$ of responders who stated they experienced benefit or were satisfied with CAM as well as those who reported adverse effects after using CAM and their cost for purchasing CAM.

\section{Results}

The searches generated 15935 articles, of which 15910 were excluded (see flow chart diagram (Figure 1)). Twenty five surveys met our eligibility criteria [2,5-28]. Detailed characteristics of the included surveys relating to CAM in general are presented in Supplimentary table. Table 1 represents the included surveys on specific CAM modalities. Fourteen surveys originated from England, 1 from England and Scotland, 1 from Scotland, 1 from Wales. The remaining 8 surveys pertained either to the whole of the UK, or their geographical location was not clearly specified.

The total number of patients included in the 25 surveys was 6798 . Twenty two surveys were on CAM in general while three were specifically on herbal medicines. Across surveys on CAM in general, the median prevalence rate since the diagnosis of cancer was $30.5(\mathrm{SD}=10.3)$. The use of a random sampling method was mentioned in 2 (8\%) surveys $[10,17]$. The median response rate was $71.0(\mathrm{SD}=14.3)$. Perceived effectiveness of CAM was mentioned in $16(64 \%)$ surveys $[2,7,9,10,13$ - 
Citation: Posadzki P, Watson LK, Alotaibi A ,Ernst E (2012) Prevalence of Complementary and Alternative Medicine-use by UK Cancer Patients: A Systematic Review of Surveys. J Integr Oncol 1:102. doi:10.4172/2329-6771.1000102

\begin{tabular}{|l|l|}
\hline Sample size (N) & $\begin{array}{l}\text { Median prevalence rate since cancer diagnosis } \\
(\text { SD) }\end{array}$ \\
\hline $0-100$ & $\begin{array}{l}32.7(7.8) \\
(\mathrm{n}=3)\end{array}$ \\
\hline $101-500$ & $\begin{array}{l}38.2(13.2) \\
(\mathrm{n}=2)\end{array}$ \\
\hline $501-$ & $\begin{array}{l}31.5(0.0) \\
(\mathrm{n}=1)\end{array}$ \\
\hline Response rate $(\%)$ & $\begin{array}{l}30.8(2.6) \\
(\mathrm{n}=2)\end{array}$ \\
\hline $50-70$ & $\begin{array}{l}31.5(0.0) \\
(\mathrm{n}=1)\end{array}$ \\
\hline $71-$ & $\begin{array}{l}31.5(1.9) \\
(\mathrm{n}=3)\end{array}$ \\
\hline Survey design & $\begin{array}{l}47.6(0.0) \\
(\mathrm{n}=1)\end{array}$ \\
\hline Postal surveys & \\
\hline Interviews & \\
\hline
\end{tabular}

Table 2: The average prevalence rates as a function of sample size, response rate and survey design.

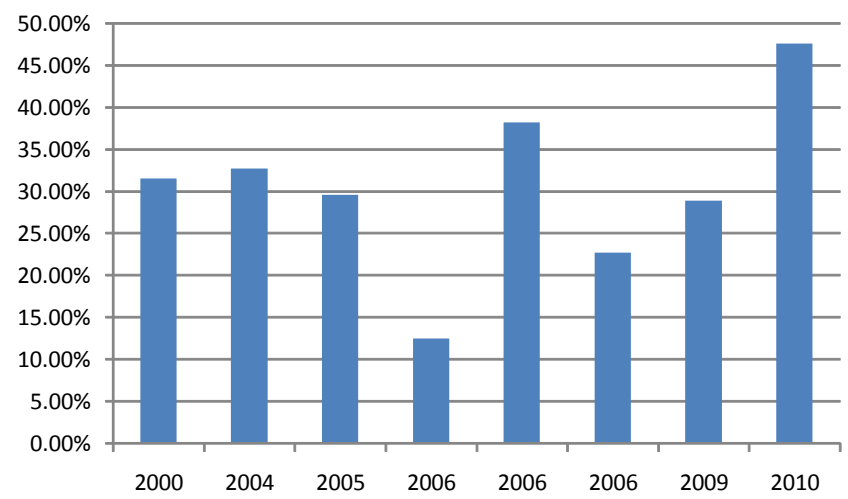

Figure 2: Prevalence of CAM-use over time (based on surveys on CAM in general, since the diagnosis of cancer).

\begin{tabular}{|c|c|}
\hline CAM modality & Conclusions regarding effectiveness available at: http://www.cam-cancer.org \\
\hline \multicolumn{2}{|l|}{ I. Herbal medicine } \\
\hline Aloe vera & $\begin{array}{l}\text { "Aloe vera gel is applied topically and is used for radiation-induced skin problems. However, clinical trials show that it is inef- } \\
\text { fective for that purpose. Aloe vera latex (juice) is taken orally. It has been insufficiently tested as a cancer therapy." }\end{array}$ \\
\hline Black cohosh (Actaea racemosa) & $\begin{array}{l}\text { "Evidence from three randomised clinical trials is not sufficient to support the use of black cohosh extracts for treatment of hot } \\
\text { flushes in breast cancer patients undergoing chemotherapy or receiving tamoxifen." }\end{array}$ \\
\hline Boswellia spp & $\begin{array}{l}\text { "No firm conclusions can be drawn on the effect of orally administered Boswellia extracts on peritumoural brain oedema, brain } \\
\text { tumours, brain metastases or any other cancer in women, men or children." }\end{array}$ \\
\hline Cannabinoids & $\begin{array}{l}\text { "The antiemetic efficacy of cannabinoids in comparison to placebo in chemotherapy-induced nausea/vomiting has been estab- } \\
\text { lished in a systematic review. The use of cannabinoids for anorexia-cachexia-syndrome in advanced cancer is not supported } \\
\text { by the evidence from randomised controlled trials. Several randomised controlled trials indicate a mild analgesic effect of } \\
\text { cannabinoids in cancer patients." }\end{array}$ \\
\hline Echinacea spp & $\begin{array}{l}\text { "Several potential uses of echinacea in cancer management have been investigated but there is currently insufficient robust } \\
\text { evidence to support these." }\end{array}$ \\
\hline Garlic (Allium sativum) & "Garlic is said to reduce the risk of certain cancers. The evidence for this assumption is encouraging but not strong." \\
\hline Green tea (Camellia Sinensis) & "The evidence for an association between green tea consumption and the incidence of cancer is generally inconsistent." \\
\hline Milk vetch (Astragalus mongolicus) & "Data from clinical trials are of low quality and need to be confirmed." \\
\hline Mistletoe (Viscum album) & $\begin{array}{l}\text { "Numerous in-vitro data suggest anti-cancer activity. Non-randomised trials suggest effectiveness. The results of rigorous } \\
\text { RCTs are, however, less convincing." }\end{array}$ \\
\hline Panax ginseng and Panax quinquefolius & $\begin{array}{l}\text { "There is preliminary evidence from two pilot studies to support the use of both ginseng-species for cancer-related fatigue. } \\
\text { P.ginseng and P. quinquefolius appear to be relatively safe when used as mono-substance and within the recommended dos- } \\
\text { age." }\end{array}$ \\
\hline St. John's wort(Hypericum perforatum) & $\begin{array}{l}\text { "Some people also promote it as a cancer drug but there is no good evidence to support this claim. St. John's wort may } \\
\text { reduce the blood levels of many conventional drugs, including some cancer medicines." }\end{array}$ \\
\hline Sweet wormwood (Artemisia annua) & "There is currently insufficient scientific evidence in humans to support the use of Artemisia in cancer patients." \\
\hline II.Homeopathy & "The evidence for homeopathy in oncology is not convincing" \\
\hline III. Aromatherapy & $\begin{array}{l}\text { "Weak evidence is available that aromatherapy can reduce anxiety, depression, sleep problems and improve a patient's gen- } \\
\text { eral wellbeing. No evidence is available for long term effects of aromatherapy (over } 2 \text { weeks)." }\end{array}$ \\
\hline IV. Reflexology & "There is insufficient objective evidence to suggest that reflexology provides valuable support for people with cancer." \\
\hline \multicolumn{2}{|l|}{ V. Relaxation } \\
\hline Progressive muscle relaxation & $\begin{array}{l}\text { "There is insufficient evidence for the effectiveness of PMR for cancer patients suffering from pain, anxiety, depression, sleep } \\
\text { disorders and chemotherapy-induced nausea." }\end{array}$ \\
\hline Autogenic training & $\begin{array}{l}\text { "Based on one clinical trial and two pilot studies, it is not possible to draw conclusions about the effectiveness of autogenic } \\
\text { therapy for people with cancer." }\end{array}$ \\
\hline
\end{tabular}

Table 3: The evidence for the 5 most popular forms of CAM.

$18,20,21,25-28]$. The median perceived effectiveness across all surveys was $42.5(\mathrm{SD}=20.2)$. Adverse effects were reported in 7 (28\%) surveys $[10,14,15,17,18,22,28]$ and the median incidence rate across all surveys was $2.5(\mathrm{SD}=4.6)$. The costs of CAM were mentioned in $11(44 \%)$ surveys $[8,9,13-20,25]$. Based on 6 surveys (in which uniform methods of reporting were employed) the median cost of CAM-use per patient

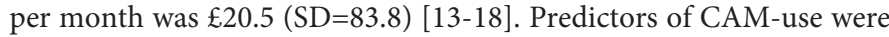
mentioned in $11(50 \%)$ surveys $[6,11-19,25]$. In the majority of those surveys, being young, highly educated and female were predictors of CAM-use. Across surveys on herbal medicines, the median prevalence rate was $51.6(\mathrm{SD}=9.4)$.

Table 2 summarizes the prevalence rates according to sample size, response rate and survey design. The median prevalence rates did not differ significantly according to response rates. In surveys with sample size of $>500$, the median prevalence rate was 31.5 which was lower than 
in surveys with sample size $>100$ and $<500$ (median of 38.2 ; $\mathrm{SD}=13.2$ ). In the survey with the lowest sample size the prevalence of CAM-use was $22.7 \%$ [18]. In the survey with the highest sample size this estimate was $31.5 \%$ [19]. In postal surveys, the median prevalence rates were much lower than those that emerged from interviews. There was no clear trend in the use of CAM over time (Figure 2).

Herbal medicine was ranked as the most popular type of CAM in 9 ( 2 in 1 ; as 3 in 2; as 4 in 0 ; as 5 in 0 ) surveys, homeopathy in 3 ( 2 in 2; as 3 in 0 ; as 4 in 0 ; as 5 in 0 ) surveys, aromatherapy in 3 ( 2 in 1; as 3 in 1; as 4 in 1; as 5 in 0 ) surveys, reflexology in 2 ( 2 in 1 ; as 3 in 1; as 4 in 0 ; as 5 in 0 ) surveys and relaxation in 1 ( 2 in 1 ; as 3 in 0 ; as 4 in 1 ; as 5 in 0 ) surveys (based on CAM in general surveys). Using our ranking method, herbal medicine was the most popular form of CAM (in $40.9 \%$ of surveys), followed by homeopathy (13.6\% of surveys) and aromatherapy (13.6\%), reflexology (9\%) and relaxation (4.5\%). The median percentage values of the 5 most popular CAM modalities are as follows: herbal medicine (30.0; $\mathrm{SD}=14.9)$, homeopathy $(13.0 ; \mathrm{SD}=11.1)$, aromatherapy (19; $\mathrm{SD}=20.9)$, reflexology $(22.5 ; \mathrm{SD}=17.6)$ and relaxation (25.7; 0.0). Reiki was also ranged as the most popular form of CAM in $4.5 \%$ of all surveys.

\section{Discussion}

Our review was aimed at summarizing and critically evaluating the evidence from surveys of CAM-use by UK cancer patients published in the past decade. Our findings suggest that, on average, almost a third of UK cancer patients used CAM since their cancer diagnosis. This figure is similar to the one found globally for any cancer [29] and for prostate cancer [30]. To the best of our knowledge, this is the first systematic review of surveys solely focusing on UK cancer patients. Our analyses suggest that the 5 most popular forms of CAM in the UK are: herbal medicine, homeopathy, aromatherapy, reflexology and relaxation.

This begs the question whether any of these treatments demonstrably generate more good than harm. In order to answer it, it is helpful to differentiate between CAM-use for curing a cancer and CAM-use for supportive or palliative cancer. None of the CAM treatments are effective cancer cures [31]. Their use for this purpose should therefore be discouraged [32].

The use of CAM for supportive or palliative care is a more complex issue [33]. The evidence for the 5 most popular forms of CAM is briefly summarized in Table 4 . It shows that the evidence is mixed but mostly not positive. Where encouraging results exist, the evidence is usually not entirely convincing. Moreover, one should acknowledge the fact that none of these treatments are devoid of risks [1]. It follows that, even for supportive and palliative cancer care, we should not uncritically recommend all forms of CAM to our patients.

Our review has several limitations that should be kept in mind when interpreting its results. Firstly, even though our searches were extensive, we cannot be entirely sure that all relevant articles were located. Secondly, since there is no gold-standard assessment tool for surveys [34] formal quality assessment was neither planned nor performed. We noticed, however, that most surveys had reasonably high response rates or used validated outcome measures. Thirdly, we only calculated the prevalence rates since/after the diagnosis of cancer [30] and omitted e.g. 12 month or lifetime ones. Fourthly, a formal metaanalysis was deemed implausible due to significant heterogeneity of the primary data. Finally, one survey did not provide with sub-group analyses [16] which prevented us from accurately calculating the total sample size across all surveys.
In conclusion, large proportions of UK cancer patients use CAM, and herbal remedies are particularly popular. Oncologists should therefore be aware of the both harms and the benefits, the use of CAM may entail.

\section{References}

1. Ernst E, Pittler MH, Wider B, Boddy K (2006) The Desktop Guide to Complementary and Alternative Medicine. (2ndedn) Edinburgh: Elsevier Mosby.

2. Molassiotis A, Cubbin D (2004) 'Thinking outside the box': complementary and alternative therapies use in paediatric oncology patients. Eur $\mathrm{J}$ Oncol Nurs 8 : 50-60.

3. Kilroy A, Adams N, Poole H (2004) Exploring cancer patients' perspectives of CAM within a primary care setting. Focus on Alternative and Complementary Therapies 9: 3

4. Stephane A Lejeune (2004) CAM and cancer. Focus on Alternative and Complementary Therapies 9: 261-262.

5. Clare S, Buxton-King A (2010) A pilot clinical service evaluation examining the usage and satisfaction of complementary therapy for patients treated in cance services at University College London Hospitals NHS Foundation Trust. Bone Marrow Transplantation: Conference.

6. Corner J, Yardley J, Maher EJ, Roffe L, Young T, et al. (2009) Patterns of complementary and alternative medicine use among patients undergoing cancer treatment. Eur J Cancer Care (Engl) 18: 271-279.

7. Lewith GT, Broomfield J, Prescott P (2002) Complementary cancer care in Southampton: a survey of staff and patients. Complement Ther Med 10: 100106

8. Needleman S (2010) The use of complementary and alternative medicines (CAM) in brain tumor patients. Neuro-Oncology: Conference.

9. Newsom-Davis T, Kenny L, Al-Shakarchi I, George J, Wong E, et al. (2009) Voodoo dolls and the cancer patient: patients do trust their doctors. QJM 102 311-319

10. van Tonder E, Herselman MG, Visser J ( 2009) The prevalence of dietary-related complementary and alternative therapies and their perceived usefulness among cancer patients. J Hum Nutr Diet 22: 528-535.

11. Zavery B, Appleton L, Sandiford K, Wong H, Hughes J (2010) Complementary and alternative medicine use amongst oncology patients attending a large cancer centre in England. Progress in Palliative Care 18: 89-93.

12. Gage H, Storey L, McDowell C, Maguire G, Williams P, et al. ( 2009) Integrated care: utilisation of complementary and alternative medicine within a conventional cancer treatment centre. Complement Ther Med 17: 84-91.

13. Harris P, Finlay IG, Cook A, Thomas KJ, Hood K (2003) Complementary and alternative medicine use by patients with cancer in Wales: a cross sectional survey. Complement Ther Med 11: 249-253.

14. Molassiotis A, Fernandez-Ortega P, Pud D, Ozden G, Platin N, et al. (2005) Complementary and alternative medicine use in colorectal cancer patients in seven European countries. Complement Ther Med 13: 251-257.

15. Molassiotis A, Fernadez-Ortega P, Pud D, Ozden G, Scott JA, et al. (2005) Use of complementary and alternative medicine in cancer patients: a European survey. Ann Oncol 16: 655-663.

16. Molassiotis A, Panteli V, Patiraki E, Ozden G, Platin N, et al. ( 2006) Complementary and alternative medicine use in lung cancer patients in eight European countries. Complement Ther Clin Pract 12: 34-39.

17. Molassiotis A, Scott JA, Kearney N, Pud D, Magri M, et al. (2006) Complementary and alternative medicine use in breast cancer patients in Europe. Support Care Cancer 14: 260-267.

18. Molassiotis A, Ozden G, Platin N, Scott JA, Pud D, et al. (2006) Complementary and alternative medicine use in patients with head and neck cancers in Europe. Eur J Cancer Care (Engl) 15: 19-24.

19. Rees R, Feigel I, Vickers A, Zollman C, McGurk R, et al. (2000) Prevalence of complementary therapy use by women with breast cancer. A population-based survey. Eur J Cancer 36: 1359-1364.

20. Scott JA, Kearney N, Hummerston S, Molassiotis A (2005) Use of complementary and alternative medicine in patients with cancer: A UK survey. Eur $\mathrm{J}$ Oncol Nurs 9: 131-137. 
Citation: Posadzki P, Watson LK, Alotaibi A ,Ernst E (2012) Prevalence of Complementary and Alternative Medicine-use by UK Cancer Patients: A Systematic Review of Surveys. J Integr Oncol 1:102. doi:10.4172/2329-6771.1000102

Page 5 of 5

21. Shakeel M, Newton JR, Bruce J, Ah-See KW (2008) Use of complementary and alternative medicine by patients attending a head and neck oncology clinic. $J$ Laryngol Otol 122: 1360-1364.

22. Werneke U, Earl J, Seydel C, Horn O, Crichton P, et al. (2004) Potential health risks of complementary alternative medicines in cancer patients. $\mathrm{Br} \mathrm{J}$ Cancer 90: 408-413.

23. Catt S, Fallowfield L, Langridge C (2006) What non-prescription treatments do UK women with breast cancer use? Eur J Cancer Care (Engl) 15: 279-285.

24. Cheetham PJ, Le Monnier KJ, Brewster SF (2001) Attitudes and use of alternative therapies in UK prostate cancer patients - isn't it time we were in the know? Prostate Cancer Prostatic Dis 4: 235-241.

25. Wilkinson S, Farrelly S, Low J, Chakraborty A, Williams R, et al. (2008) The use of complementary therapy by men with prostate cancer in the UK. Eur J Cancer Care (Engl) 17: 492-499.

26. Helpman L (2010) Complementary/alternative medicine use among women receiving chemotherapy for ovarian cancer: A comparison of attitudes between two patient populations. Gynecologic Oncology: Conference S108.

27. Gami B, Harrington K, Blake P, Dearnaley D, Tait D, et al. (2003) How patients manage gastrointestinal symptoms after pelvic radiotherapy. Aliment Pharmacol Ther 18: 987-994
28. Sharples FM, Van Haselen R, Fisher P (2003) NHS patients' perspective on complementary medicine: a survey. Complement Ther Med 11: 243-248.

29. Ernst E, Cassileth BR (1998) The prevalence of complementary/alternative medicine in cancer: a systematic review. Cancer 83: 777-782.

30. Bishop FL, Rea A, Lewith H, Chan YK, Saville J, et al. (2011) Complementary medicine use by men with prostate cancer: a systematic review of prevalence studies. Prostate Cancer Prostatic Dis 14: 1-13.

31. Chanda P, Furnham A (2008) Does homeopathy work? Part II: A review of recent scientific papers. Focus on Alternative and Complementary Therapies 13 157-167.

32. Calman B, Ernst E (2007) A bewildering journey through 'alternative' medicine. Focus on Alternative and Complementary Therapies 12: 167-169.

33. Wyatt B, Furnham A (2010) The medical consultation: what do users and nonusers of CAM value? Focus on Alternative and Complementary Therapies 15 $88-96$

34. Sanderson S, Tatt ID, Higgins JP (2007) Tools for assessing quality and susceptibility to bias in observational studies in epidemiology: a systematic review and annotated bibliography. Int J Epidemiol 36: 666-676. 